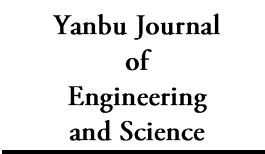

ISSN: 1658-5321
Vol. 2, April $2011(1432 \mathrm{H})$

www.yic.edu.sa/yjes

\title{
AN EXPERIMENTAL STUDY OF THE TEMPERATURE DISTRIBUTION DUE TO BENZENE FIRE UNDER FORCED VENTILATION
}

\author{
Bahgat. K. Morsy ${ }^{1}$, S.Al. A.Abed Al Gany ${ }^{2}$ and Fahad Al-Mufadi ${ }^{1}$ \\ ${ }^{1}$ Mechanical Engineering Department,College of Engineering, Qassim University, bahgat@qec.edu.sa \\ ${ }^{2}$ Lecturer, Egypt Universities, Bani Suef, Bani suef, Egypt \\ ${ }^{1}$ Mechanical Engineering Department, College of Engineering, Qassim University
}

\begin{abstract}
This work aims to study the effective parameters on forced ventilation by which the fire can be put under control. There are many parameters which specify the forced ventilation such as angle of louvers 'supply air grill'; this parameter was investigated experimentally using a modified test rig in order to supply different ventilation rates into the compartment with different angle of louvers 'supply air grill' while different types of fuel with different masses were used. In this paper was concerned on benzene fuel of 13.2 gram when the fuel mass less than $13.2 \mathrm{~g}$ no clear differences in temperature distribution. To perform this study a modified test room was designed. Results of the study show that the effect of angle of louvers 'supply air grill' and ventilation rate on fire depression (minimum fire duration) in a compartment is mainly represented in the high values of angle of louvers 'supply air grill' by $75^{\circ}$ (equivalent ventilation factor $0.0215 \mathrm{~m}^{5 / 2}$ ) and low values of speed of extracting fans (equivalent ventilation rate $0.067 \mathrm{~m}^{3} / \mathrm{s}$ ) for benzene (gasoline fuel) at different fuel masses. Also, results indicate that a decreasing in angle of louvers 'supply air grill' and increasing in ventilation rates result in undesirable effects as the fire duration increased.
\end{abstract}

KEYWORDS: Forced ventilation, Temperature, Benzene fire

\section{INTRODUCTION}

Fire is indeed a major risk for residential, traffic and industrial installations. In the case of residential installation accidental fires result in billions of dollars of property damage, and many murdered people, per year. In the case of traffic installation or tunnels fire cause damage to the wall of tunnel which subjected to convective and radioactive heat fluxes from both the flame and the plume gases.

Types of ventilation are, natural which is created by natural forces that result from difference in the distribution of air pressure around a building, since air always flows from area of high pressure to area of low pressure. Some times natural ventilation can not circulate enough air through a building. So forced ventilation creates air flow in rooms or building that would otherwise be stagnant. Forced ventilation can be used to supplement both horizontal and vertical ventilation.

Types of fire can be divided into three types, the first type is the fully fire in this type of fire complete burn-out of fire area is assumed. The second type is the limited growth fire this type of fire is a fire which produces a thermal column sufficient to create a heated layer of gases in the upper elevation of the room involved in the fire. And the third type is the 
limited growth, smoky fire a limited growth, smoky fire is a fire such as smoldering rags or an electrically indicated cable fire [1]. A pool fire is a type of turbulent diffusion flame, which burns above a pool of vaporizing fuel where the fuel vapor has negligible initial momentum. Fire accidents form an important part of all accidents which occurred in the industry and in transport of hazardous materials; fire is involved in $41.4 \%$ of all these events [1]. Studying the effect of ventilation rate and ventilation factor on enclosure fire is therefore important. The ventilation rate depends on the use of the buildings and their floor area. Usually the smaller the floor area, the larger the ventilation rate consumed. Large open-area offices might have a ventilation rate of about $10 \mathrm{~m}^{3}$ air change per hour, smaller compartments, would have a higher ventilation rate up to $50 \mathrm{~m}^{3}$ air change per hour [2].

E. Planas-couchi et al. [1] conducted a largescale tests in pool- fires in which a horizontal cylindrical tank was engulfed in the fire. They should that for a certain fire sizes; flame temperature is not constant over all the fire. In case of hexane pool-fires shows the temperature decreases with height. However, for larger fires (kerosene) the experimental values of flame temperature did not change with height according to any definite pattern.

W. K. Chow [2] carried out his experiment in a fire chamber of length $4.0 \mathrm{~m}$, width $3.0 \mathrm{~m}$ and height $2.8 \mathrm{~m}$ and the forced ventilation fires were studied by locating the fire source in a chamber at different positions under different ventilation rates. The mass loss rate of the fuel, temperature distribution in the chamber and the air flow rates at intake and outlet openings were measured. And he showed that under conditions of low heat release rate and high ventilation rates, the smoke temperature can be calculated from:
$\mathrm{Q}_{\mathrm{M}}=\mathrm{m}_{\mathrm{g}} \mathrm{c}_{\mathrm{p}}\left(\mathrm{T}-\mathrm{T}_{\mathrm{o}}\right)+\mathrm{Q}_{\text {loss. }}$

$\mathrm{He}$ also carried out full-scale tests with wood cribs and methanol in fire chamber of length $4.0 \mathrm{~m}$, width $3.0 \mathrm{~m}$ and height $2.8 \mathrm{~m}$ to study the pre flash over stage of a compartmental fire and the effect of ventilation. The mass loss rate of fuel, temperature distribution in the compartment, air flow rates, oxygen, carbon monoxide and carbon dioxide concentrations at the outlet openings were measured. And they decided that for forced ventilation fire, the ventilation rate has a significant effect on the burning process, the peak rate of heat release would be decreased as the ventilation rate increased. Also they mentioned that the ventilation factor has a significant effect in fire control when the ventilation factor was $<0.02 \mathrm{~m}^{5 / 2}$.

W. K. Chow [3] decided his experiment in a fire chamber of length $4.0 \mathrm{~m}$, width $3.0 \mathrm{~m}$ and height $2.8 \mathrm{~m}$ and the forced ventilation fires were studied by locating the fire source in a chamber at different positions under different ventilation rates. The mass loss rate of the fuel, temperature distribution in the chamber and the air flow rates at intake and outlet openings were measured. And he showed that under conditions of low heat release rate and high ventilation rates, the smoke temperature can be calculated from equation (1).

W. K. Chow [4] was suggested a full-scale burning test on wood, PMMA (polymethylmethacrylate) and methanol fires with forced ventilation in a fire chamber of length $4.0 \mathrm{~m}$, width $3.0 \mathrm{~m}$ and height $2.8 \mathrm{~m}$. The gas temperatures at seven positions were measured together with the transient mass loss rate of the fuel. And he concluded that the heat loss coefficient $\left(h_{k}\right)$ included both convective and radioactive effects of the walls, ceiling, and floors can be calculated by the expression below when time $(\mathrm{t})$ is smaller than 
the thermal penetration time $t_{\mathrm{p}}$

$\mathrm{h}_{\mathrm{k}}=\mathrm{C}_{1} \operatorname{Max}\left[\sqrt{\left(\mathrm{K}_{\mathrm{w}} \rho_{\mathrm{w}} \mathrm{C}_{\mathrm{w}} / \mathrm{t}\right)} \cdot\left(\mathrm{K}_{\mathrm{w}} / \delta_{\mathrm{w}}\right)\right]$

Where, $t_{p}$ is in fact the time taken for the thermal wave generated inside the room to reach the exterior surface of the wall and is given by,

$\mathrm{t}_{\mathrm{P}}=\left(\rho_{W} \mathrm{C}_{\mathrm{W}} / \mathrm{K}_{\mathrm{W}}\right) \times\left(\delta_{\mathrm{W}} / 2\right)^{2}$

In the above expression, $\mathrm{t}$ is the time, $\mathrm{K}_{\mathrm{w}}$, $\rho_{\mathrm{w}}, \mathrm{C}_{\mathrm{w}}$ and $\delta_{\mathrm{w}}$ the thermal conductivity, density, specific heat capacity, and thickness of the wall, respectively. The parameter $C_{1}$ is taken to be $(0.165)$. If time taken for all the fire tests were smaller than $t_{p}$ the equation of $\mathrm{h}_{\mathrm{k}}$ will be applied.

K. T. Yang et al. [5] performed a full-scale forced ventilation fire in a test room which has a height of $5 \mathrm{~m}$ and contains two double doors, the ventilation exhaust located above the entry room. And they made a numerical simulation; the numerical simulation based on a fire field model showed that during the first four minutes of the fire the hot gas has already penetrated into the floor region. Other than to fire plume region and regions that are immediately affected by the ventilation inlet and outlet, the temperature fields are essentially stably stratified into layer structures.

C. Qian et al. [6] developed a pool fire apparatus with a temperature and fuel level control, radial and axial temperature distribution for five different small diameter pool fires were measured by the IR IMAGE temperature measurement technique, and velocity of fuel, oxidizer and the air entrainment near the base of the pool were measured by a particle-track LASER sheet technique. And he decided that the structure of a flame base is always laminar regardless of pool diameter, at least for pool fires with diameter between $5 \mathrm{~cm}$ and $50 \mathrm{~m}$. This observation suggested that mechanisms of air entrainment and flame structure near the base for a large-scale pool fire can be studied from a small-scale laboratory pool fire. Also they decided that air entrainment and fuel air mixing which occur near the base of pool fires influence soot production rate, flame height and temperature structure.

R. O. Carvel et al. [7] achieved their studies in a tunnel of $9.5 \mathrm{~m}$ wide and $6.4 \mathrm{~m}$ height, they used three different pool sizes, square pool (25 $\left.\mathrm{m}^{2}\right)$, small rectangular pool $\left(10 \mathrm{~m}^{2}\right)$ and large rectangular pool $\left(100 \mathrm{~m}^{2}\right)$. They noticed that if there is a pool fire in a tunnel, any forced longitudinal ventilation applied will tend to reduce the severity of the fire unless the fire is very large, in which case the ventilation will cause the fire to increase in severity.

H. B. Awbi [8] illustrated that the removal of smoke takes excessive heat away from the fire zones of the buildings as well as lowering the indoor air temperature and radiant temperature. Then a smoke extraction system or ventilation system is most needed in public buildings such as shopping malls, leisure centers and airport terminals.

S. H-K. Lee et al. [9] showed that at low pressure, the mass flow rate of air into the enclosure was independent of temperature difference between the ambient and the enclosure or the vent length. However, at high pressure the flow rate increases with decreasing vent length and temperature difference.

M. Walters et al. [10] after examining a number of disastrous fires concluded that the fire become a disaster and governments adopt fire safety legislation and consider whether performance codes would provide a more a appropriate regulatory environment. The purpose of the present work is to study the influence of some main parameters have a significant effect on the fire depression in compartmental fire under forced ventilation, among these parameters are: ventilation rate 
$(\dot{\mathrm{V}})$, angle of louvers 'supply air grill' $\left(\mathrm{F}_{\mathrm{V}}\right)$ and the effect of angle of louvers 'supply air grill' on the temperature distribution through vertical heights.

The objective of this experimental work is to study the effect of changing the angle of louvers 'supply air grill' by $30^{\circ}, 45^{\circ}, 60^{\circ}, 75^{\circ}$ and $90^{\circ}$ ) and the ventilation rates (by change the speed of extracting fans by 2868, 2846, 2810 and 2765 r.p.m.). The speed of fans was changed by using a voltage regulator after that it was measured by electrical tachometer.

To study this parameter, a test rig has been modified with dimensions of $(100 \mathrm{~cm}$ height, $100 \mathrm{~cm}$ width and $75 \mathrm{~cm}$ length). The room was provided by inlet air opening of $(26.5 \mathrm{~cm}$ width and $26 \mathrm{~cm}$ height) with seven movable louvers and two outlet ducts of $18 \mathrm{~cm}$ diameter in which two axial fans were fixed. A variable amount of ventilation rates $(0.162$, $0.131,0.078$ and $0.067 \mathrm{~m}^{3} / \mathrm{s}$ ) and different angle of louvers 'supply air grill' $\left(30^{\circ}, 45^{\circ}, 60^{\circ}\right.$, $75^{\circ}$ and $90^{\circ}$ ) was put under study. The test room is provided by one inlet opening with flexible louvers (supply air grill) in order to control the angle of louvers 'supply air grill' by changing the angle of opening for the louvers "angle of inclination". And two circular outlet openings in the top of the room were used. The test room has a thermal sight glass to observe the experiment procedures.

\section{MEASURING TECHNIQUE}

The inlet temperature and velocities of air have been measured by using manufactured and calibrated hot wire anemometer. Temperatures inside the room have been measured through vertical positions $(\mathrm{y} / \mathrm{H}=$ $0.25,0.375,0.5,0.625,0.75,0.875$ and 1.0 ) by using a manufactured thermocouple from type 'J' connected to a "Fluke Helios I data logger" to record temperature readings instantaneously for all measuring points at the same time for every scan. In the outlet openings there are two suction fans which are fixed in order to enable the change of air speed extraction rate and then change the ventilation rate. Exhaust velocities are measured by using hot wire anemometer.

\section{EXPERIMENTAL TEST RIG, THE TEST ROOM LOUVERS AND THERMAL GLASS}

The test rig consists of the following parts: test room, louvers (supply air grill), thermal glass, ducts, extraction or suction fans, combustion pans, electrical ignition coil, and necessary measuring instruments.

Experiments were carried out in the climate chamber. The room dimensions are: $100 \mathrm{~cm}$ height, and cross section of $(100 \mathrm{~cm} \times 75 \mathrm{~cm})$ Figs. (1, 2) shows a schematic layout of the test rig and its main components. An experimental room was designed to study the effect of forced ventilation on a compartmental fire under variable amounts of ventilation rates and different angle of louvers 'supply air grill'. Air was supplied into the room at a constant temperature (the average ambient air temperature) through the louvers openings. The inlet temperature and velocities of air were measured by using manufactured and calibrated hot wire anemometer. Chamber walls are made from wood sheets (outer walls of $1 \mathrm{~cm}$ thickness) and steel sheets of $0.08 \mathrm{~cm}$ thickness (inner walls) and between them filled with $5 \mathrm{~cm}$ of insulation material of wood particles.

However the air indoor temperature has been measured through seven vertical planes distributed upstream through thermocouple rake with seven thermocouples labeled $T_{1}$ to $\mathrm{T}_{7}$ and spaced at $125 \mathrm{~mm}$ intervals. There is another measuring point from the same type in the center of the room labeled $\mathrm{T}_{8}$ to measure the smoke temperature. 


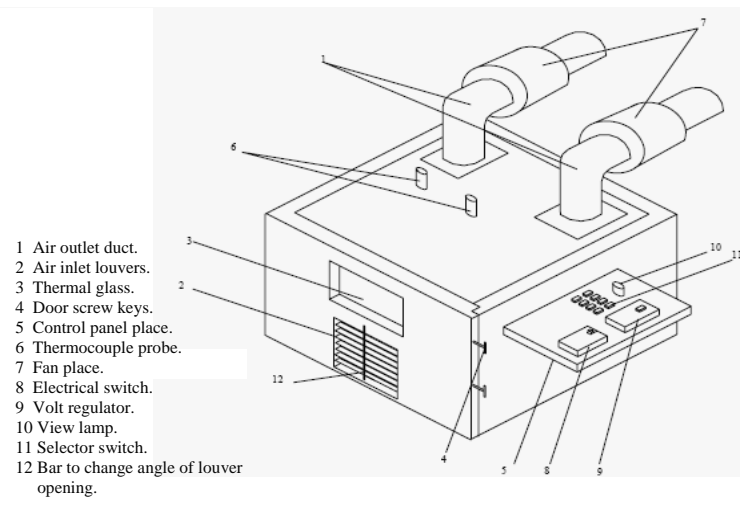

Fig. 1. Layout of the test rig.

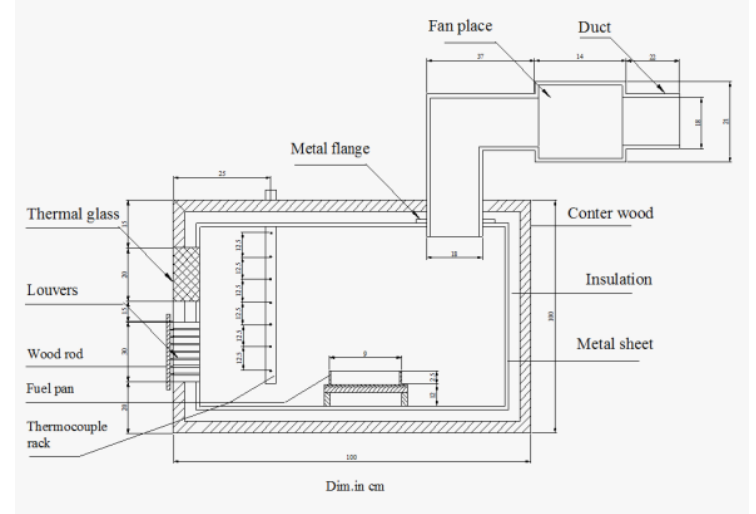

Fig. 2. A-A section in the test room.

Temperature measurement points showed in figure (3) Thermal glass has thickness of 5 $\mathrm{mm}$. and area of $(40 \mathrm{~cm} \times 20 \mathrm{~cm})$ fixed in the front of the chamber to enable the observation of the experimental procedures and the flame inside the chamber.

There are two ducts to extract the exhaust gases from the chamber each duct is supported on the ceiling of the chamber by flanges and insulated by a suitable insulation material. The dimensions of each duct are 50 $\mathrm{cm}$ height and $18 \mathrm{~cm}$ diameter and enlarged in the center of part two $(21 \mathrm{~cm}$ diameter $)$ to fix the fan. Ducts were made from steel sheet of thickness $0.8 \mathrm{~mm}$ and constructed in this way for the following reasons:

1- To put the fan far from the flame source to protect it from unexpected high temperature. 2- To fix the fan axially as it designed. From the calibration curve for thermocouple probe the main observation is that the deviation of the data logger thermocouple readings curve than the reference curve is small, so that the readings which have been taken by the data logger thermocouple can be used directly without calibration.

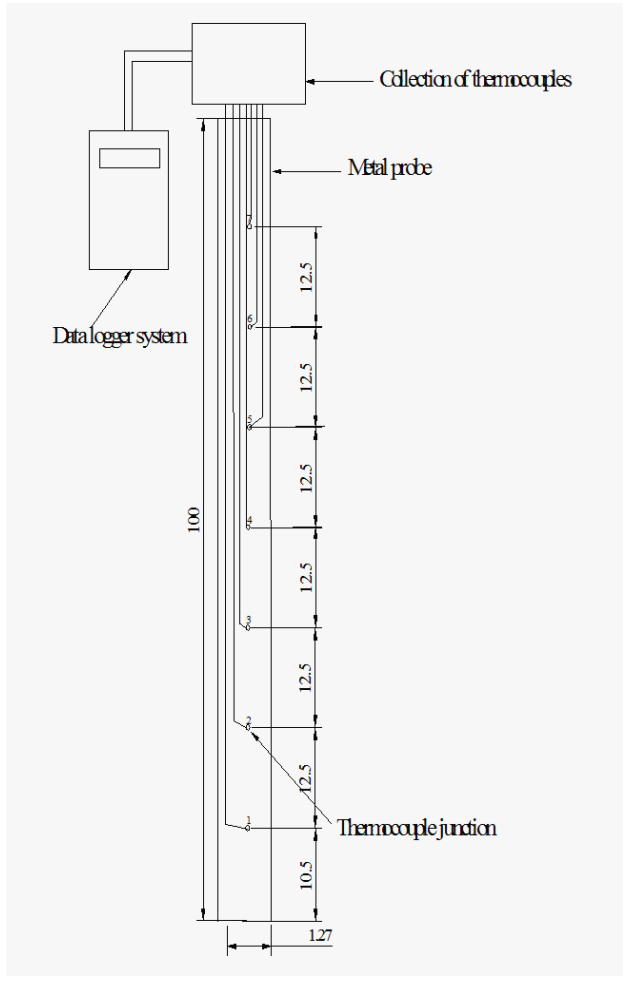

Fig. 3. Temperature measurement points and thermocouple probe (dimensions in $\mathrm{mm}$ ).

\section{ANALYSIS AND DISCUSSION OF EXPERIMENTAL RESULTS}

The main objectives of this section are to present and discuss the recorded results of the experiments to investigate the effect of angle of louvers 'supply air grill' on the temperature distribution, the heat released rate in a compartmental fire as well as the effect of ventilation rate on the fire duration at the following operating conditions:

1 - Benzene at mass of $13.2 \mathrm{~g}$.

2- Angle of louvers 'supply air grill' of $30^{\circ}, 45^{\circ}$, $60^{\circ}, 75^{\circ}$ and $90^{\circ}$ equivalent ventilation factor (Fv) were calculated as 0.0006, 0.0041, 0.011, 0.0215 and $0.0219 \mathrm{~m}^{5 / 2}$ respectively.

3- Ventilation rate of $0.162,0.131,0.078$ and $0.067 \mathrm{~m}^{3} / \mathrm{s}$. 
In the following section, the measured values of vertical temperatures on the compartment versus time at the effect of ventilation factor and vertical height are plotted in Figures below.

\subsection{EFfect OF Ventilation Factor ON THE TeMPerature ProfiLe For BENZENE}

4.1.1. Results at fuel mass of $m=13.2 \mathrm{~g}, \mathrm{y} / \mathrm{H}=\mathbf{0 . 2 5}$ and different ventilation rates

Figure (4.1) indicates the relationship between the temperature profile and time of combustion at different ventilation rates. The test conditions were: measuring point is $(y / H=0.25)$ and different ventilation factors. By comparing the figures, the following may be observed:

1- For all Fv values temperature profile illustrated that at the measuring point $(y / H=0.25)$ temperature increased from its minimum value at the beginning of combustion process to reach maximum value and then decreased according to the fire vanished by time.

2- For different values of ventilation rates as ventilation rate decreased the beginning temperature increased, because the inlet amount of ventilation rate reduce the compartmental inside temperature by cooling the inner zone of the compartment.

3- The Fv intensively affects the values of temperature, which observed from the temperature profile as follows:

- For $\mathrm{Fv}_{\mathrm{v}}<0.02 \mathrm{~m}^{5 / 2}$, the maximum values of temperature differences were low and for $\mathrm{Fv}>0.02 \mathrm{~m}^{5 / 2}$, the maximum values of temperature differences were high as shown in Fig. (4.1 a) and (4.1 b) this observation coincides with the findings of the reviewed literature [17].

- For Fv equal to $0.0215 \mathrm{~m}^{5 / 2}$ and $\dot{\mathrm{V}}=0.067$

$\mathrm{m}^{3} / \mathrm{s}$ the temperature profile indicated that the temperature reached its maximum value about $58{ }^{\circ} \mathrm{C}$ and the fire duration was the minimum value about $130 \mathrm{~s}$ as shown in Figs $(4.1 \mathrm{c})$ and $(4.1 \mathrm{~d})$ this observation may be resulted from the rapid combustion of fuel as the mass of fuel were constant then heat released rate affected by the fire duration, as fire duration is small then heat released rate is high.

4- For natural ventilation as shown in Fig. (4.1 e) the main observation was that the temperature profile for natural ventilation when the door of the compartment closed was higher than that for natural ventilation when door of compartment opened. This observation may be a result of the cooling process which occurred when door is opened then the amount of heat dissipated to the atmosphere outside the compartment is higher than the case of closed compartment door.

\subsubsection{Results at fuel mass of $m=13.2 \mathrm{~g}, \mathrm{y} / \mathrm{H}=\mathbf{0 . 3 7 5}$ and different ventilation rates}

Figure (4.2) shows the relationship between the temperature profile and time of combustion at different ventilation rates. By investigating the results of the different cases of ventilation rates $\dot{V}$ may show that the observations for the previous case, i.e. $(\mathrm{Y} / \mathrm{H}=0.25)$ are also applicable in this case but the fire duration was minimum about $140 \mathrm{~s}$ at $\mathrm{Fv}=0.0215 \mathrm{~m}^{5 / 2}$ and $\dot{V}=0.067 \mathrm{~m}^{3} / \mathrm{s}$.

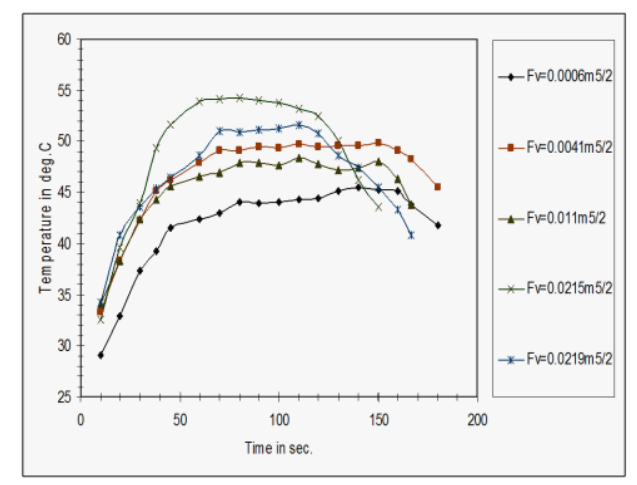

(a) 


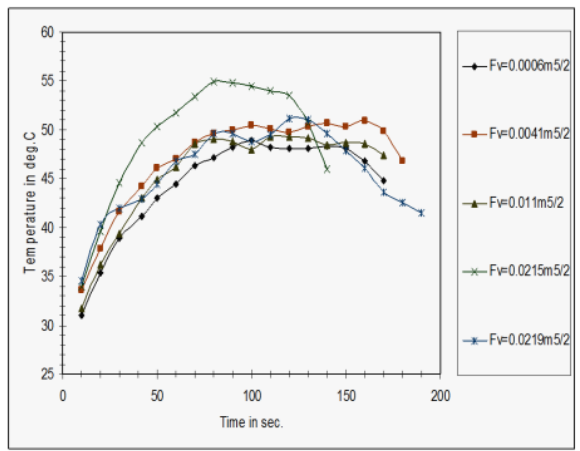

(b)

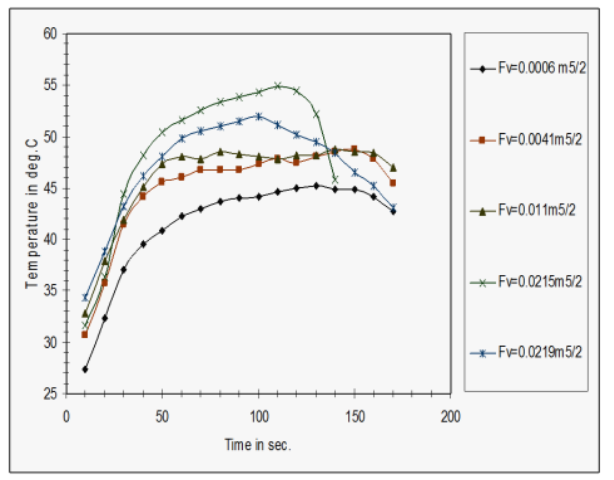

(c)

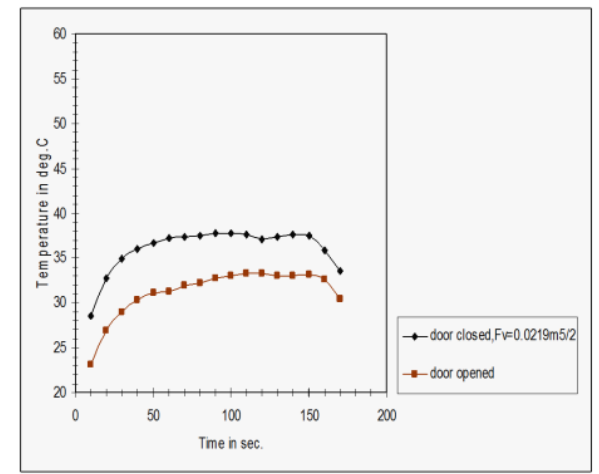

(d)

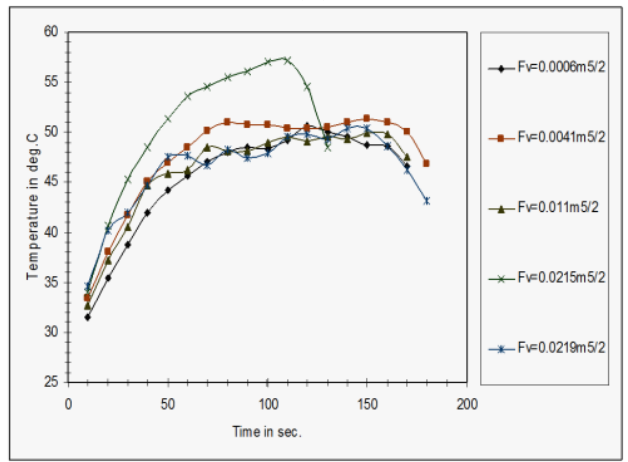

(e)

Fig. 4.1 Effect of ventilation factor on temperature profile versus time at $\mathrm{y} / \mathrm{H}=0.25$; benzene $\mathrm{C}_{6} \mathrm{H}_{6}$;

(a) Ventilation rate $\left(\dot{V}_{1}\right)=0.162 \mathrm{~m}^{3} / \mathrm{s}$;

(b) Ventilation rate $\left(\dot{V}_{2}\right)=0.131 \mathrm{~m}^{3} / \mathrm{s}$;

(c) Ventilation rate $\left(\dot{\mathrm{V}}_{3}\right)=0.078 \mathrm{~m}^{3} / \mathrm{s}$;

(d) Ventilation rate $\left(\dot{\mathrm{V}}_{4}\right)=0.067 \mathrm{~m}^{3} / \mathrm{s}$;

(e) Natural ventilation

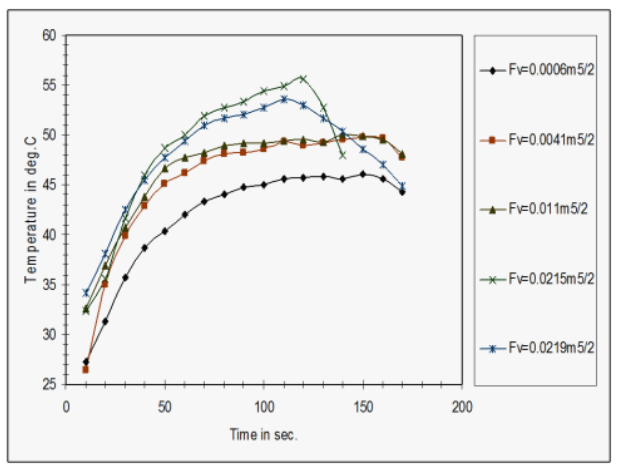

(a)

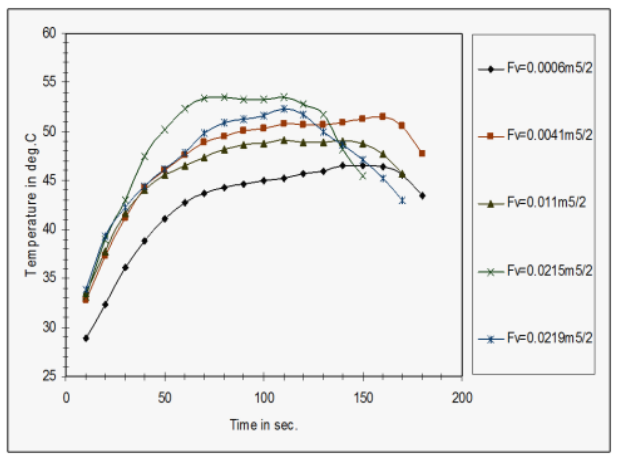

(b)

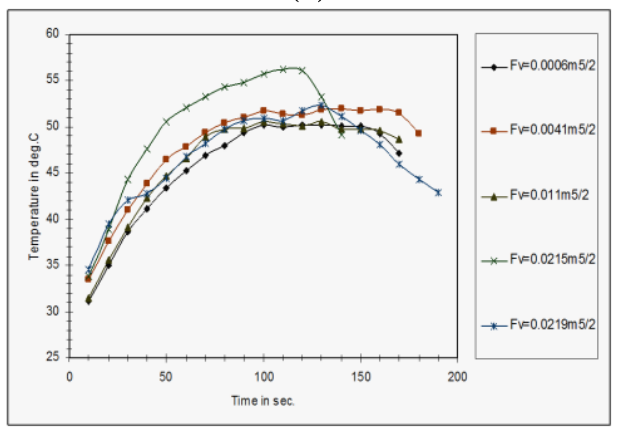

(c)

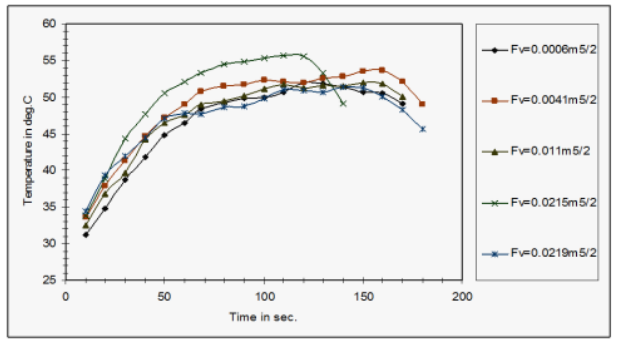

(d)

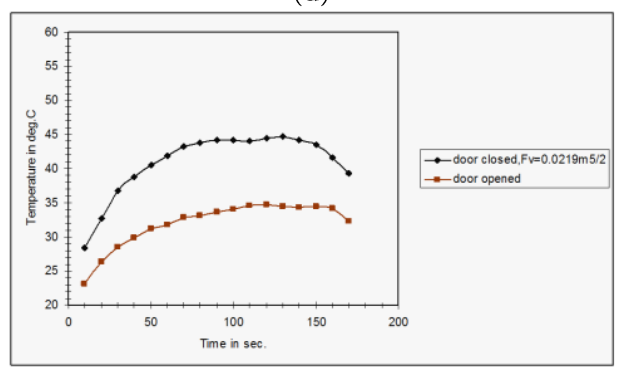

(e)

Fig.4.2 Effect of ventilation factor on temperature 
profile versus time at $\mathrm{y} / \mathrm{H}=0.375$; benzene $\mathrm{C}_{6} \mathrm{H}_{6}$;
(a) Ventilation rate $\left(\dot{V}_{1}\right)=0.162 \mathrm{~m}^{3} / \mathrm{s}$;
(b) Ventilation rate $\left(\dot{\mathrm{V}}_{2}\right)=0.131 \mathrm{~m}^{3} / \mathrm{s}$;
(c) Ventilation rate $\left(\dot{\mathrm{V}}_{3}\right)=0.078 \mathrm{~m}^{3} / \mathrm{s}$;
(d) Ventilation rate $\left(\dot{\mathrm{V}}_{4}\right)=0.067 \mathrm{~m}^{3} / \mathrm{s}$;
(e) Natural ventilation.

4.1.3 Results at fuel mass of $\mathrm{m}=13.2 \mathrm{~g}, \mathrm{y} / \mathrm{H}=\mathbf{0 . 5}$ and different ventilation rates:

Figure (4.3) illustrates the relationship between the temperature profile and time of combustion at different ventilation rates. By investigating the results of the different cases of ventilation rates $\dot{V}$ may show that all observation obtained for the previous cases, $(y / H)=0.25$ and $(y / H)=0.375$ can be applicable here.

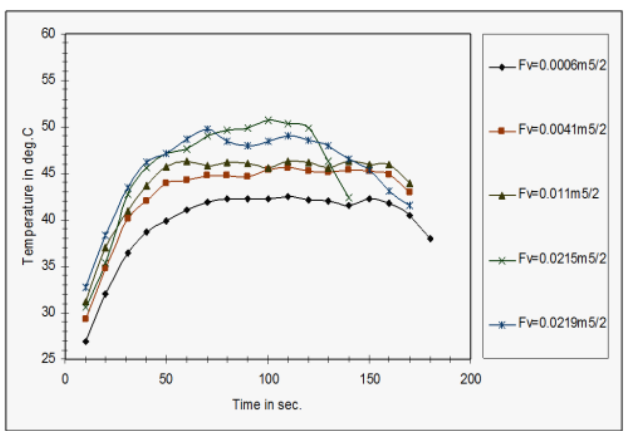

(a)

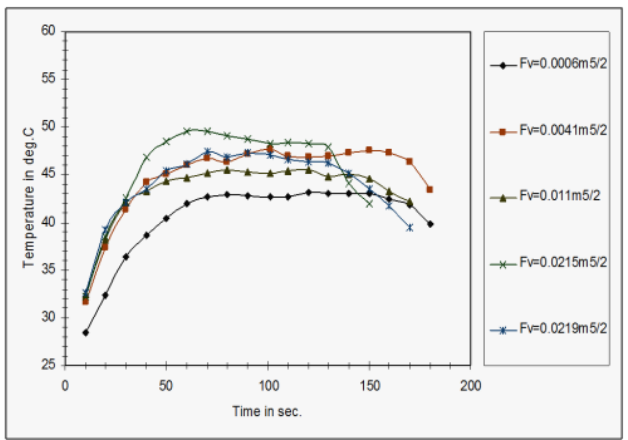

(b)

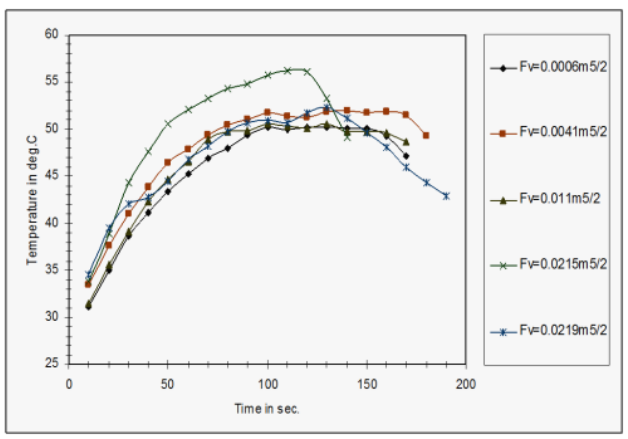

(c)

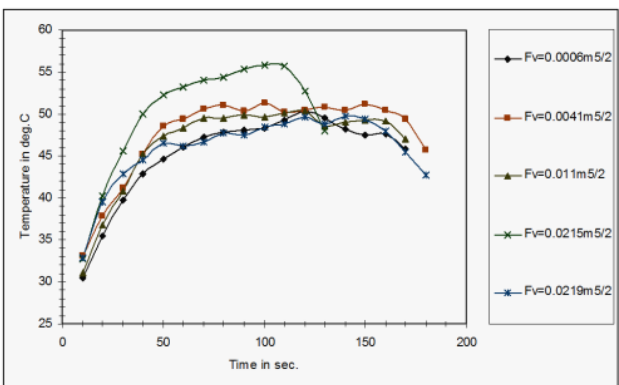

(d)

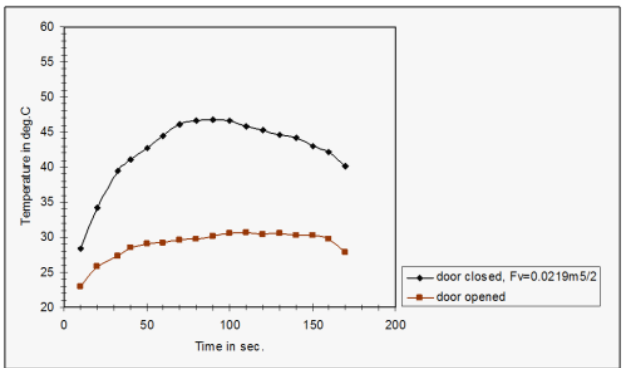

(e)

Fig. 4.3 Effect of ventilation factor on temperature profile versus time at $y / \mathrm{H}=0.5$; benzene $\mathrm{C}_{6} \mathrm{H}_{6}$;

(a) Ventilation rate $\left(\dot{\mathrm{V}}_{1}\right)=0162 \mathrm{~m}^{3} / \mathrm{s}$;

(b) Ventilation rate $\left(\dot{\mathrm{V}}_{2}\right)=0.131 \mathrm{~m}^{3} / \mathrm{s}$;

(c) Ventilation rate $\left(\dot{V}_{3}\right)=0.078 \mathrm{~m}^{3} / \mathrm{s}$;

(d) Ventilation rate $\left(\dot{\mathrm{V}}_{4}\right)=0.067 \mathrm{~m}^{3} / \mathrm{s}$;

(e) Natural ventilation.

4.1.4 Results at fuel mass of $m=13.2 \mathrm{~g}, \mathrm{y} / \mathrm{H}=$ 0.625 and different ventilation rates

Figure (4.4) indicates the relationship between the temperature profile and duration of combustion at different ventilation rates. By investigating the results of the different cases of ventilation rates $\dot{V}$ may show that the observations for the previous cases, i.e. $(y / H)$ $=0.25,0.375$ and 0.5 are also applicable in this case. In addition the maximum values temperature differences for different $\mathrm{Fv}$ is observed clearly at $\dot{V}=0.162$ and $0.131 \mathrm{~m}^{3} / \mathrm{s}$ as shown in Figs. (1.4 a) and (1.4 b) this observation may be resultant of the cooling process which occurred by adding fresh air with high ventilation rate into the compartment. Then the maximum values temperature differences decreased as ventilation rate increased. 


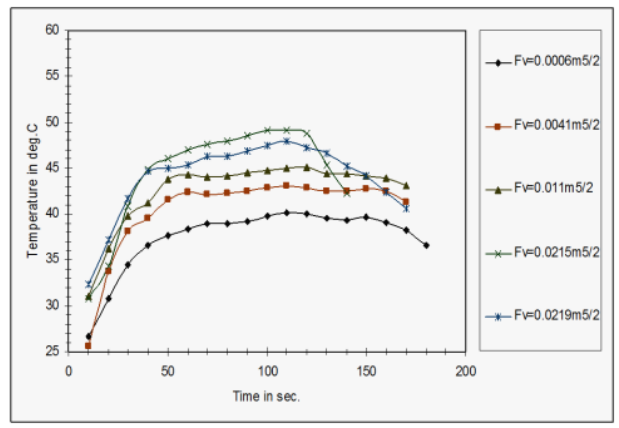

(a)

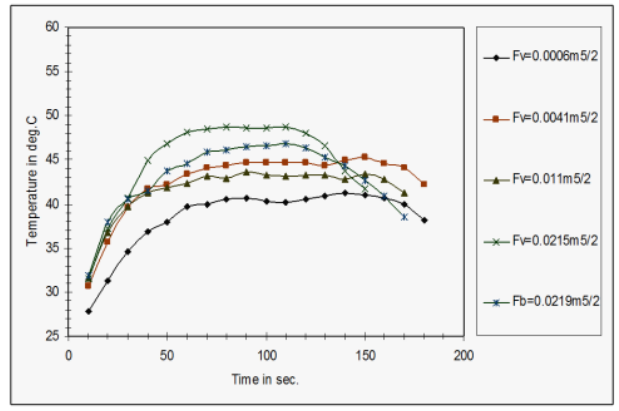

(b)

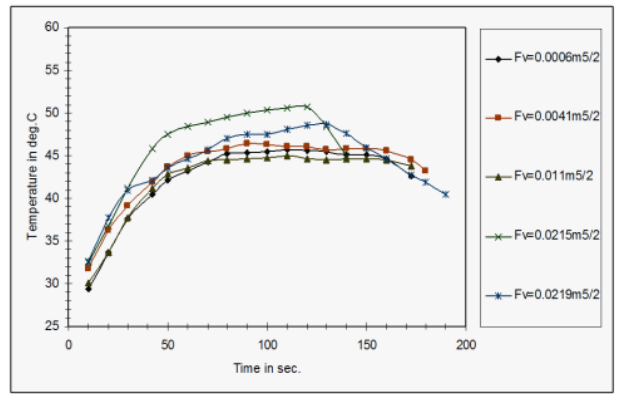

(c)

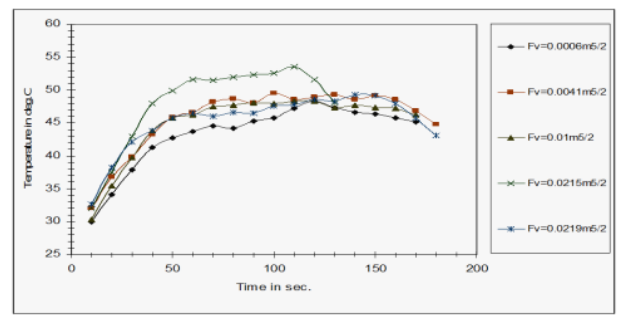

(d)

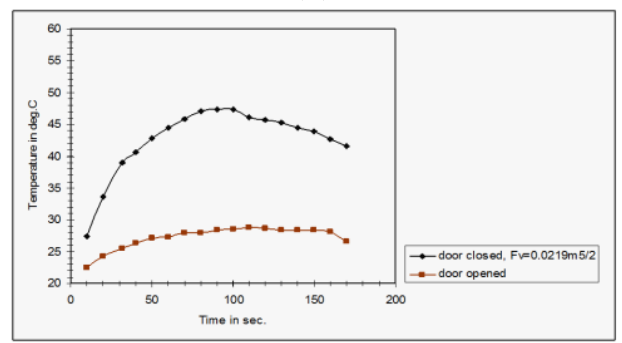

(e)

Fig.4.4 Effect of ventilation factor on temperature profile versus time at $\mathrm{y} / \mathrm{H}=0.625$; benzene $\mathrm{C}_{6} \mathrm{H}_{6}$;

(a) Ventilation rate $\left(\dot{V}_{1}\right)=0.162 \mathrm{~m}^{3} / \mathrm{s}$;

(b) Ventilation rate $\left(\dot{V}_{2}\right)=0.131 \mathrm{~m}^{3} / \mathrm{s}$; (c) Ventilation rate $\left(\dot{\mathrm{V}}_{3}\right)=0.078 \mathrm{~m}^{3} / \mathrm{s}$;

(d) Ventilation rate $\left(\dot{V}_{4}\right)=0.067 \mathrm{~m}^{3} / \mathrm{s}$;

(e) Natural ventilation.

4.1.5 Results at fuel mass of $\mathrm{m}=13.2 \mathrm{~g}, \mathrm{y} / \mathrm{H}=0.75$ and different ventilation rates:

Figure (4.5) shows the relationship between the temperature profile and time of combustion at different ventilation rates. By investigating the results of the different cases of ventilation rates $\dot{V}$ may show that the observations for the previous case, $(y / H)=$ 0.625 are also applicable in this case.

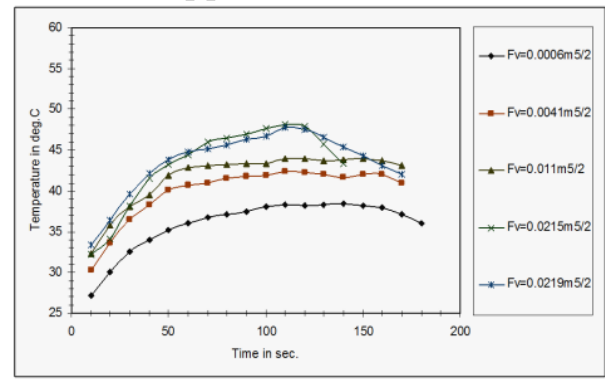

(a)

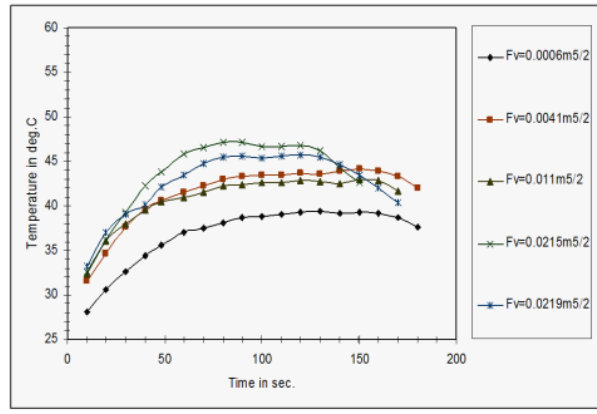

(b)

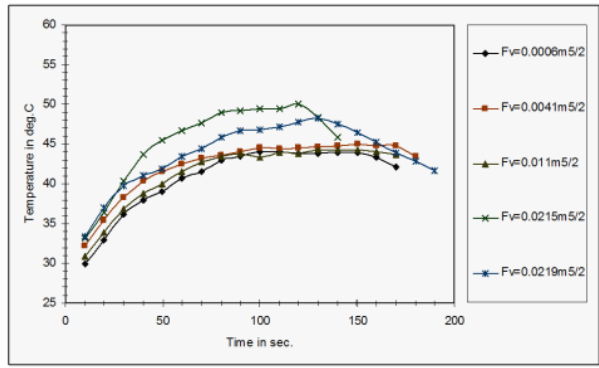

(c)

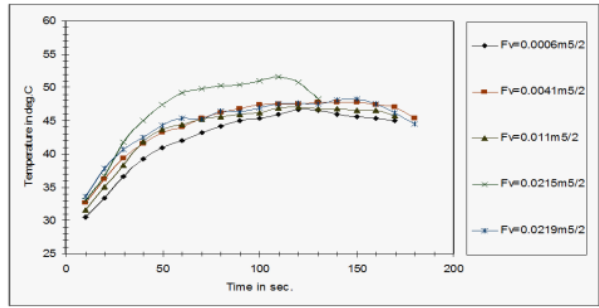

(d) 


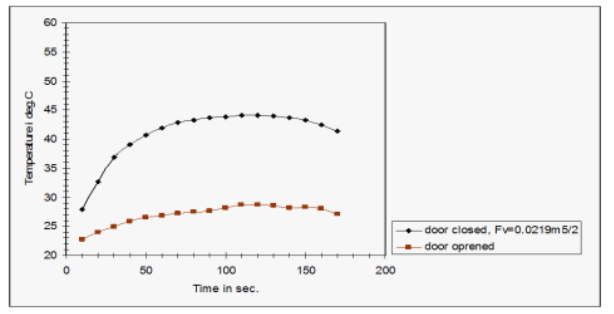

(e)

Fig.4.5 Effect of ventilation factor on temperature profile versus time at $\mathrm{y} / \mathrm{H}=0.75$; benzene $\mathrm{C}_{6} \mathrm{H}_{6}$;
(a) Ventilation rate $\left(\dot{V}_{1}\right)=0.162 \mathrm{~m}^{3} / \mathrm{s}$;
(b) Ventilation rate $\left(\dot{\mathrm{V}}_{2}\right)=0.131 \mathrm{~m}^{3} / \mathrm{s}$;
(c) Ventilation rate $\left(\dot{\mathrm{V}}_{3}\right)=0.078 \mathrm{~m}^{3} / \mathrm{s}$;
(d) Ventilation rate $\left(\dot{\mathrm{V}}_{4}\right)=0.067 \mathrm{~m}^{3} / \mathrm{s}$;
(e) Natural ventilation.

4.1.6 Results at fuel mass of $\mathrm{m}=13.2 \mathrm{~g}, \mathrm{y} / \mathrm{H}=\mathbf{0 . 8 7 5}$ and different ventilation rates

Figure (4.6) illustrates the relationship between the temperature profile and the duration of combustion at different ventilation rates. By investigating the results of the different cases of ventilation rates $\dot{V}$ may show that the observations for the previous case, i.e $(y / H)=0.625$ and 0.75 are also applicable in this case.

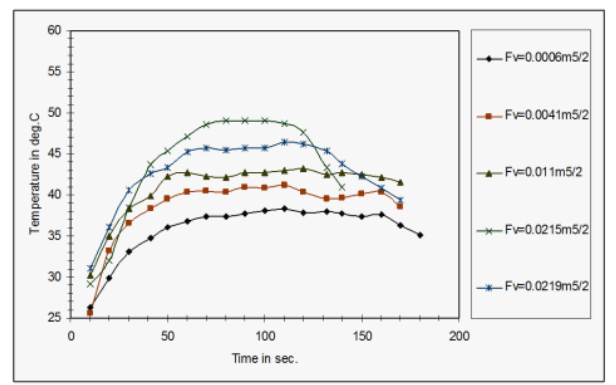

(a)

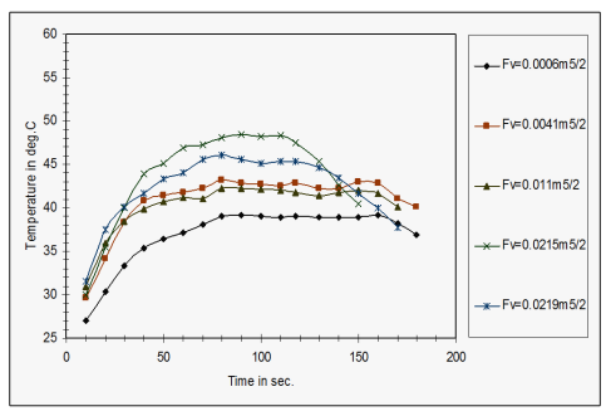

(b)

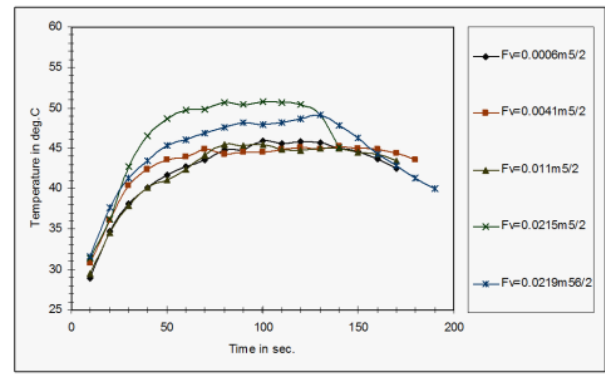

(c)

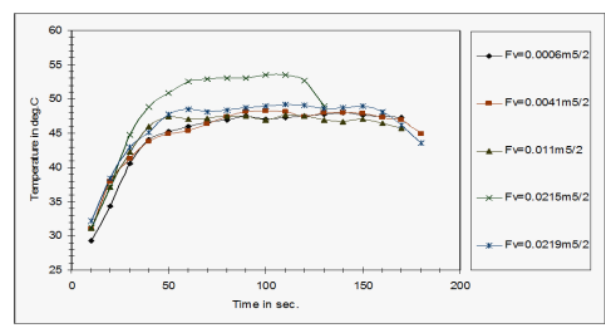

(d)

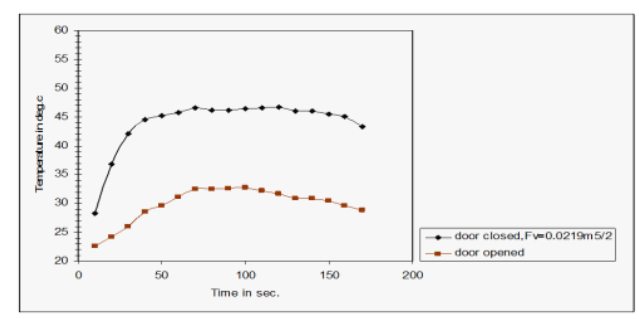

(e)

Fig.4.6 Effect of ventilation factor on temperature profile versus time at $y / \mathrm{H}=0.875$; benzene $\mathrm{C}_{6} \mathrm{H}_{6}$;

(a) Ventilation rate $\left(\dot{V}_{1}\right)=0.162 \mathrm{~m}^{3} / \mathrm{s}$;

(b) Ventilation rate $\left(\dot{V}_{2}\right)=0.131 \mathrm{~m}^{3} / \mathrm{s}$;

(c) Ventilation rate $\left(\dot{V}_{3}\right)=0.078 \mathrm{~m}^{3} / \mathrm{s}$;

(d) Ventilation rate $\left(\dot{\mathrm{V}}_{4}\right)=0.067 \mathrm{~m}^{3} / \mathrm{s}$;

(e) Natural ventilation.

4.1.7. Results at fuel mass of $m=13.2 \mathrm{~g}, \mathrm{y} / \mathrm{H}=\mathbf{1 . 0}$ and different ventilation rates

Figure (4.7) illustrates the relationship between the temperature profile and time of combustion at different ventilation rates. By investigating the results of the different cases of ventilation rates $\dot{V}$ may show that the observations for the previous case, i.e. $(\mathrm{Y} / \mathrm{H})$ $=0.625,0.75$ and 0.875 are also applicable in this case. 


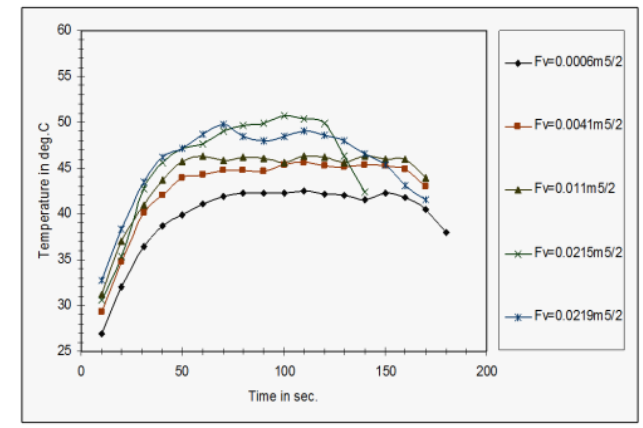

(a)

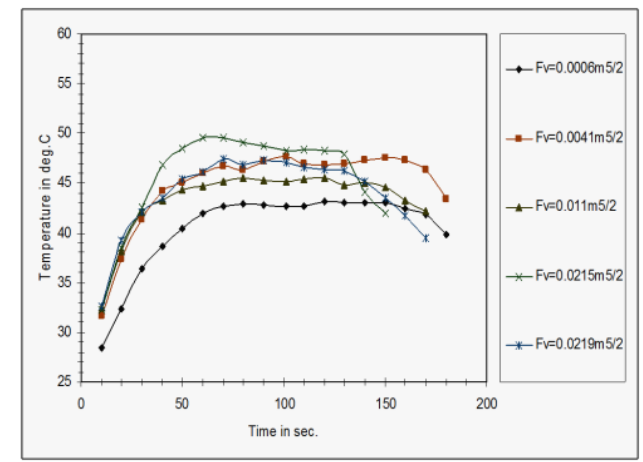

(b)

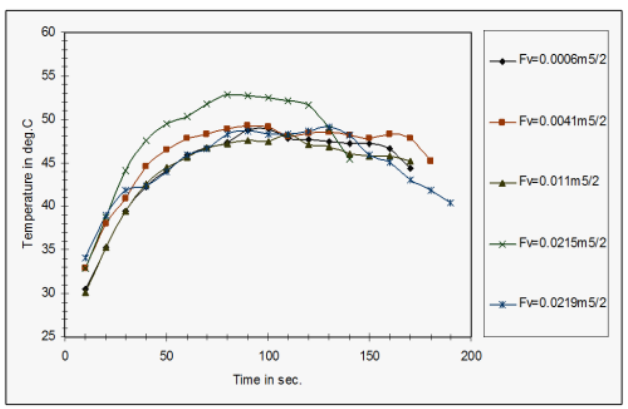

(c)

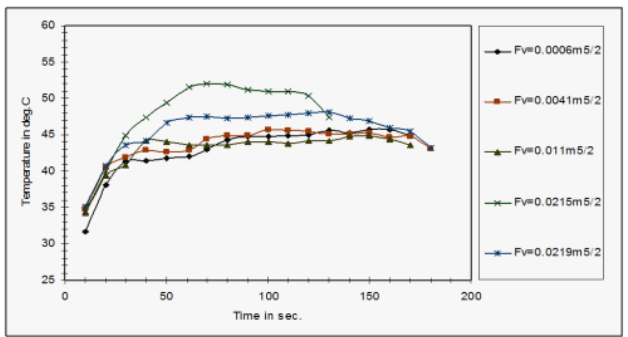

(d)

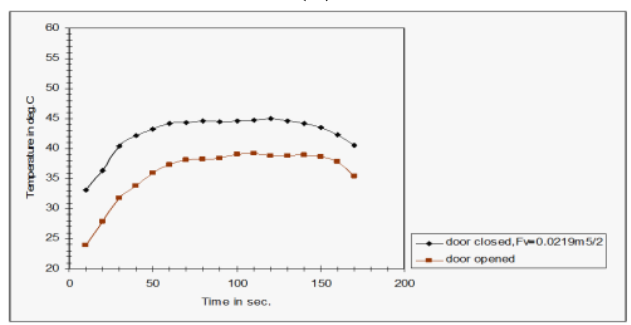

(e)

Fig.4.7 Effect of ventilation factor on temperature profile versus time at $\mathrm{y} / \mathrm{H}=1.0$; benzene $\mathrm{C}_{6} \mathrm{H}_{6}$; (a) Ventilation rate $\left(\dot{V}_{1}\right)=0.162 \mathrm{~m}^{3} / \mathrm{s}$; (b) Ventilation rate $\left(\dot{\mathrm{V}}_{2}\right)=0.131 \mathrm{~m}^{3} / \mathrm{s}$;

(c) Ventilation rate $\left(\dot{V}_{3}\right)=0.078 \mathrm{~m}^{3} / \mathrm{s}$;

(d) Ventilation rate $\left(\dot{V}_{4}\right)=0.067 \mathrm{~m}^{3} / \mathrm{s}$;

(e) Natural ventilation.

4.1.8. Results at fuel mass of $m=13.2 \mathrm{~g}$, smoke temperature and different ventilation rates

Figure (4.8) shows the relationship between the temperature profile and time of combustion at different ventilation rates. By investigating the results of the different cases of ventilation rates $\dot{V}$ may show that:

1- For all Fv values temperature profile illustrated that for smoke, temperature increased from its minimum value at the beginning of combustion process to reach maximum value and then decreased as the fire vanished by time.

2- For different values of ventilation rates as ventilation rate decreased the beginning temperature increased, because the inlet amount of ventilation rate reduce the compartmental inside temperature by supplying fresh amount of air into the compartment.

3- The Fv has a significant effect on the values of temperature, which observed from the temperature profile as follows:

- The maximum temperature of the smoke were recorded at $\mathrm{Fv}=0.0215 \mathrm{~m}^{5 / 2}$ for $\dot{\mathrm{V}}=0.162$ and $0.131 \mathrm{~m}^{3} / \mathrm{s}$ as shown in Fig (4.8 a) and $(4.8 \mathrm{~b})$, but by decreasing the amount of ventilation rate to $0.067 \mathrm{~m}^{3} / \mathrm{s}$ the maximum smoke temperature were reached at the smallest value of $\mathrm{Fv}=0.0006 \mathrm{~m}^{5 / 2}$, but the minimum fire duration were recorded at the condition of $\mathrm{Fv}=0.0215 \mathrm{~m}^{5 / 2}$ and $\dot{\mathrm{V}}=0.067$ $\mathrm{m}^{3} / \mathrm{s}$ as shown in Fig. ( $4.8 \mathrm{~d}$ )

- For natural ventilation as shown in Fig. (4.8 e) the main observation was that the temperature profile for natural ventilation when the door of the compartment was closed was higher than that for natural ventilation 
when door of compartment was opened and the temperature difference between maximum values were high. This observation may be a result of the cooling process which occurred when door is opened then the amount of heat lost to the atmosphere outside the compartment is higher than the case of closed compartment door.

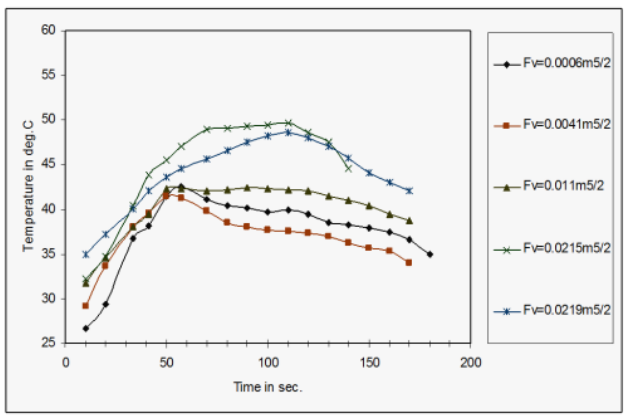

(a)

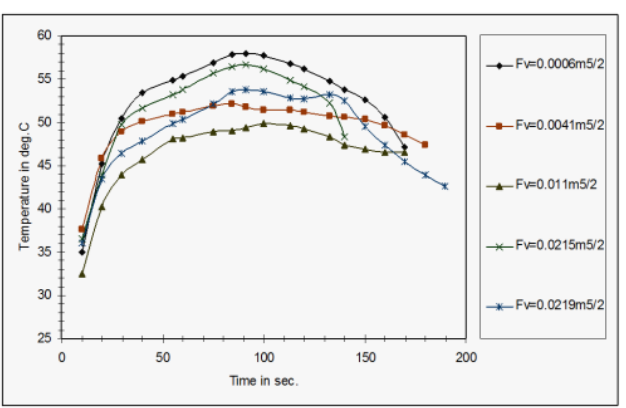

(b)

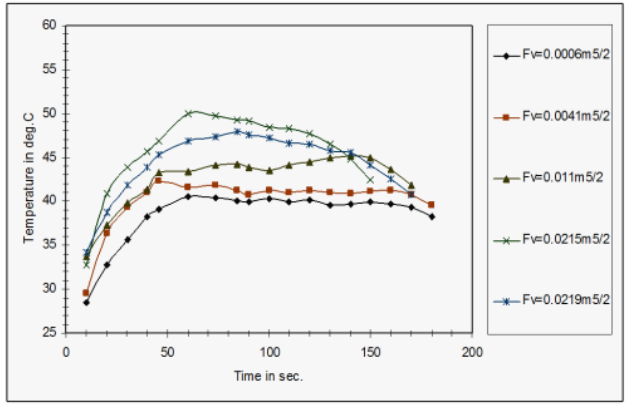

(c)

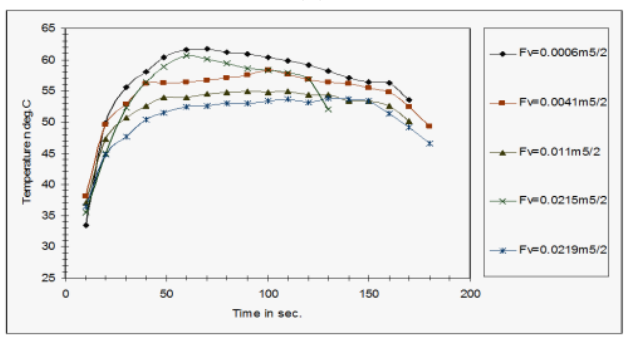

(d)

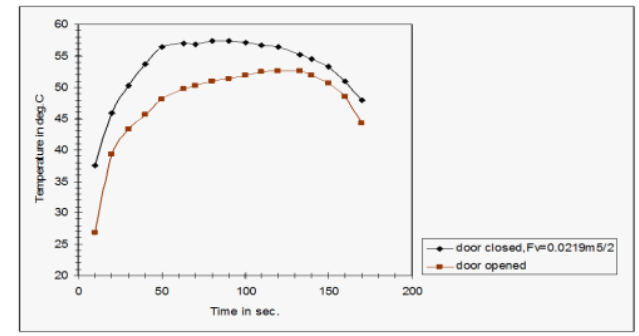

(e)

Fig. 4.8 Effect of ventilation factor on temperature profile versus time at smoke temperature; benzene $\mathrm{C}_{6} \mathrm{H}_{6}$
(a) Ventilation rate $\left(\dot{\mathrm{V}}_{1}\right)=0.162 \mathrm{~m}^{3} / \mathrm{s}$;
(b) Ventilation rate $\left(\dot{\mathrm{V}}_{2}\right)=0.131 \mathrm{~m}^{3} / \mathrm{s}$;
(c) Ventilation rate $\left(\dot{V}_{3}\right)=0.078 \mathrm{~m}^{3} / \mathrm{s}$;
(d) Ventilation rate $\left(\dot{\mathrm{V}}_{4}\right)=0.067 \mathrm{~m}^{3} / \mathrm{s}$;
(e) Natural ventilation.

\subsubsection{Results at natural ventilation and different vertical positions $(\mathrm{y} / \mathrm{H})$.}

Figure 4.9 shows the relationship between the temperature profile and time of combustion at different ventilation factors. Fig. 4.9 a Effect of ventilation factor on temperature profile versus time at smoke temperature; benzene $\mathrm{C}_{6} \mathrm{H}_{6}$; (a) Ventilation rate $\left(\dot{\mathrm{V}}_{1}\right)$ $=0.162 \mathrm{~m}^{3} / \mathrm{s}$; (b) Ventilation rate $\left(\dot{\mathrm{V}}_{2}\right)=0.131$ $\mathrm{m}^{3} / \mathrm{s}$; (c) Ventilation rate $\left(\dot{\mathrm{V}}_{3}\right)=0.078 \mathrm{~m}^{3} / \mathrm{s}$; by investigating the results of the two cases for natural ventilation the following observations may be obtained:

1- At the compartment door was opened the temperature difference between maximum value of smoke temperature and maximum value of temperature at vertical position $(\mathrm{y} / \mathrm{H})$ $=1.0$ is high about $15^{\circ} \mathrm{C}$.

2- The maximum temperature was smoke temperature followed by temperature at vertical position $(y / H)=1.0$ this observation is the result of natural ventilation as there is no buoyancy of air inside the compartment then at the upper hot layer of the compartment the hot air (smoke) going upstream as shown in Fig. (4.9 a)

3- At door closed the effect of ventilation 
factor was observed clearly, as temperature at vertical position $(y / H)=1.0$ not differed by high value than any vertical position. But smoke temperature remained the maximum temperature in the compartment as shown in Fig. 4.9 b.

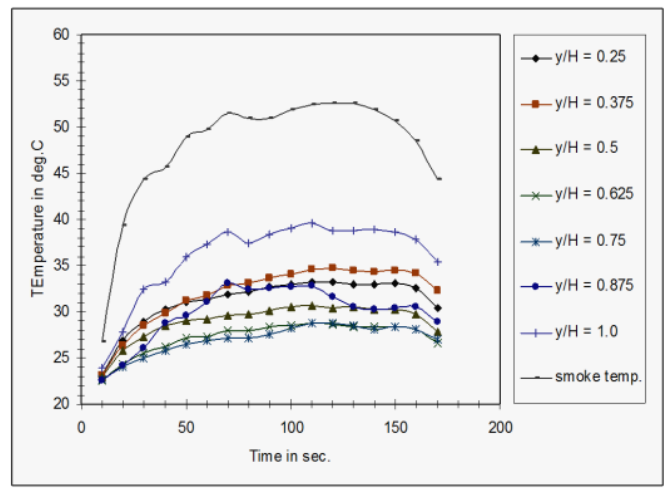

(a)

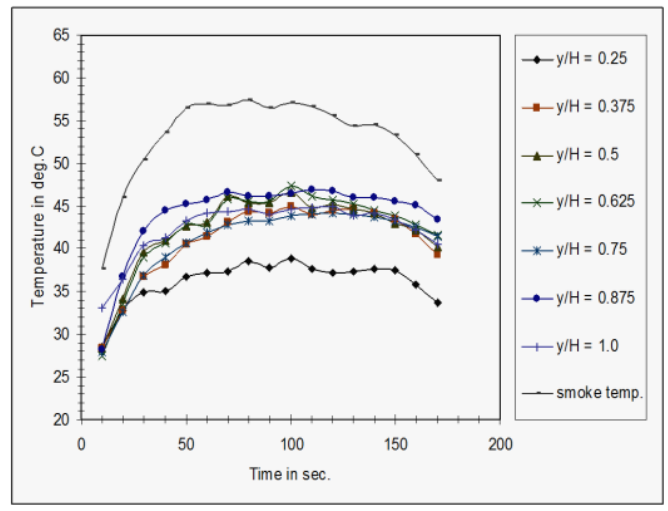

(b)

Fig. 4.9 Temperature profile at natural ventilation, benzene;
(a) At door opened;
(b) At door closed, $\mathrm{Fv}=0.0219 \mathrm{~m}^{5 / 2}$.

\subsubsection{Effect of Ventilation Rate on Fire Duration for benzene}

Figure 4.10 shows the relationship between fire duration and ventilation factor at different ventilation rates. The calculations were made at fuel mass $=13.2 \mathrm{~g}$ of benzene. By investigating the resultant figure the main important observation was that the minimum fire duration was obtained at $\mathrm{Fv}=0.0215 \mathrm{~m}^{5 / 2}$ and $\dot{V}=0.067 \mathrm{~m}^{3} / \mathrm{s}$. This observation may be the result of the rapid combustion of fuel as mass of fuel was constant.

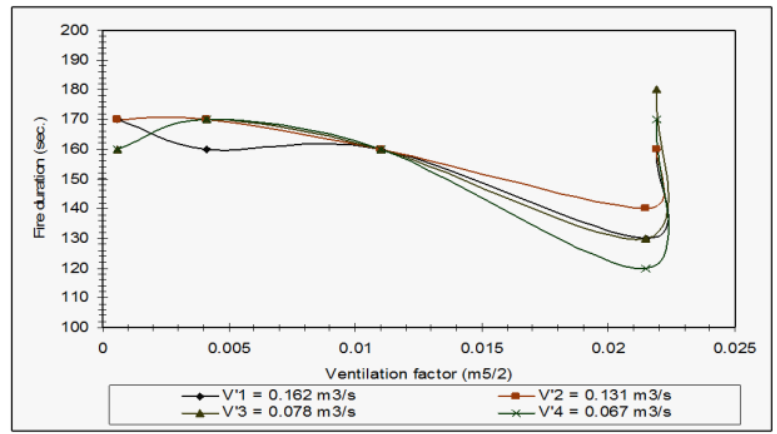

Fig. 4.10 Effect of ventilation rate on fire duration at different ventilation factors for benzene, fuel mass = $13.2 \mathrm{~g}$.

\section{CONCLUSION}

The results of experimental tests conducted on the compartmental fire under forced and natural ventilation are concluded in the following points:

1. The maximum temperature for benzene combustion according to any measuring point $(\mathrm{y} / \mathrm{H})$ were recorded at $\mathrm{Fv}=0.0215$ $\mathrm{m}^{5 / 2}$ and minimum $\dot{\mathrm{V}}=0.067 \mathrm{~m}^{3} / \mathrm{s}$ ) and minimum fire duration was obtained at this condition. But for smoke or exhaust gases maximum temperature were occurred at (minimum ventilation factor $\mathrm{Fv}_{\mathrm{V}}=0.0006 \mathrm{~m}^{5 / 2}$ and minimum $\dot{\mathrm{V}}=0.067$ $\left.\mathrm{m}^{3} / \mathrm{s}\right)$.

2. For forced ventilation on benzene combustion process the minimum value of temperature was related to vertical position $\mathrm{y} / \mathrm{H}=1.0$, but maximum temperature was obtained at vertical position $\mathrm{y} / \mathrm{H}=0.375$ due to $\mathrm{Fv}=0.0215$ $\mathrm{m}^{5 / 2}$ also minimum fire duration occurred at this case. By increasing the ventilation factor the maximum temperature was noticed at smoke temperature and smoke layer appeared to be in a different thermal stratified layer by comparing with the thermal stratified layer of air at any measuring point. 
3. For natural ventilation on benzenes combustion process without the effect of ventilation factor the maximum temperature was related to the exhaust gases followed by the temperature of vertical location of $y / H=1.0$. In contrary for natural ventilation with the effect of ventilation factor the maximum temperature was also the smoke temperature but not followed by the temperature of vertical location $\mathrm{y} / \mathrm{H}=1.0$.

4. The maximum heat released rate was obtained at $\mathrm{Fv}=0.0215 \mathrm{~m}^{5 / 2}$ and $\dot{\mathrm{V}}=0.067$ $\mathrm{m}^{3} / \mathrm{s}$ for liquid fuel. .

5. The recommended ventilation factors on compartmental fire under forced ventilation with liquid fuel it should be $>0.0215 \mathrm{~m}^{5 / 2}$, otherwise the decreasing of ventilation factor result in undesirable effects i.e. increasing the fire duration.

\section{ACKNOWLEDGEMENT}

This research was funded through the Deanship of Scientific research at Qassim University Grant.

\section{REFERENCES}

[1] Planas-Cuchi E. and Casal J., "Flame temperature distribution in a pool fire", Journal of Hazardous Materials, Vol. 62, 1998, pp. 231-241.

[2] Chow W. K., "Use of zone models on simulating compartmental fires with forced ventilation", Fire and materials, Vol. 19, 1995, pp. 101-108.

[3] Chow W. K., "On the temperatures in forced ventilation fires", ASHRAE Transactions, annual meeting, 2000, pp. 298-303.

[4] Chow W. K. and Ng Y. S., "Experimental studies of compartmental fire", Journal of Applied Fire Science, Vol. 4(1), 1994-1995, pp. 17-30.

[5] Yang K. T. and Nicolette V. F., "Field model simulation of full-scale forced ventilation roomfire test in the HDR facility in Germany", HTD
- Vol. 272, heat transfer in fire and combustion systems, ASME 1994.

[6] Qian C., Tashtoush G., Ito A. and Saito K., "Structure of large scale pool fires", International conference on fire research and engineering, Orlando, September 10- 15, 1995.

[7] Carvel R. O., Beard A. N. and Jowitt P. W., "The effect of forced longitudinal ventilation on a pool fire in a tunnel", Interflam'99',Edinburgh, Scotland, Proceeding Vol. 2, $29^{\text {th }}$ June $-1^{\text {st }}$ July 1999, pp. 1267-1272.

[8] Awbi H. B., 'Ventilation of buildings, $1^{\text {st }}$ Edition, Clays Ltd, St Ives plc, Bungay, Suffolk, 1991.

[9] H-K S., Lee, Chiu W. K. S. and Jaluria Y., "Experimental Study of Enclosure Fires With Horizontal Vents", Combustion Institute/Eastern States Section, Chemical and Physical Process in Combustion, Technical Meeting, October 25-27, 1993. Princeton, NJ, 1993, pp. 327-330.

[10] Walters M. and Hastings E. M., "Fire safety legislation in Hong Kong", Facilities Vol. 16. Number 9/10. September / October 1998. pp. 246-253. 


\title{
دراسة عملية لتوزيع درجات العرارة الناتجة عن حريق البنزين داخل غرفة معرضة لتهوية قسرية
}

\section{بهجت خميس مرسى 1، سيف النصر احمد عبد الغنى2، فهز المفضي1}

\author{
1 قسم الهنسة الميكانيكية، كلية الهندسة، جامعة القصيم، المملكة العربية السعودية \\ البريد الإلكتروني: bahgat52@yahoo.com

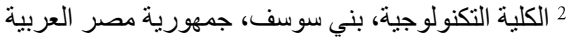

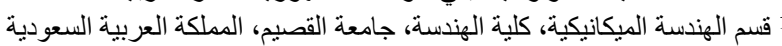

الملخص:

تهدف الدراسة إلى دراسة العوامل المؤثرة على التهوية القسرية والتي من خلالها يتم السيطرة علي هناك العديد من المعاملات التي تحدد التهوية القسرية مثل معامل التهوية ومعدل التهوية وهذين العاملين تم التحقق منها عمليا باستخدام جهاز اختبار معد لللك بحيث يقوم بإمداد معدلات تهوية مختلفة داخل الغرفة مع معاملات تهوية

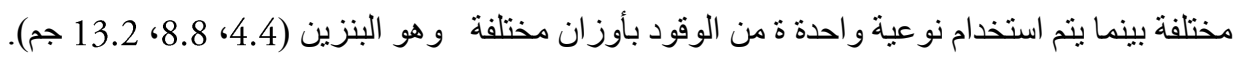
و لأجر اء هذه الدر اسة تم تصميم و إنشاء غرفة اختبار بأبعاد (100سم ارتفاع، ومساحة مقطع 75 سم * 100سم) بفتحات دخول الهواء على هيئة نافذة ( 26.5 سم عرض × 26 سم ارتفاع) بها عدد 7 عوارض متحركة والغرفة بها ماسورنان للعادم قطر كل منهما 18 سم مثبت بداخل كل منها مروحة سحب. ولقد أخذ في الاعتبار عند تصميم التحكم في كميات مختلفة من معدلات التهوية (0.162، 0.131، 0.078، 0.067 م3/ث) ومعاملات تهوية مختلفة (0.0006، 0.004، 0.011، 0.0219 م ) وضعت تحت الاختبار. درجة حرارة دخول الهواء وسر عته تم قياسهما باستخدام مقياس السرعة المعاير ذو السلك الساخن. درجات الحر ارة داخل الغرفة تم قياسها

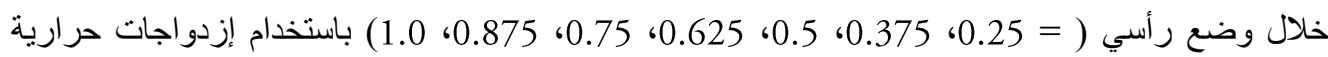
مصنعة من النوع موصلة علي جهاز تجميع للبيانات لحظيا لكي يسجل قراءات درجات الحرارة لكل نقاط

$$
\text { القياس في نفس الوقت لكل عملية مسح. }
$$

وبينت النتائج مدى تأثير معامل التهوية ومعدلات التهوية على إخماد الحرائق (أقل زمن لاستمرار الحريق) داخل الغرفة تمثلت أساسا عند القيم العالية لمعامل التهوية بقيم تفوق 0.0215 م، وكذلك عند القيم المنخفضة لمعدلات التهوية بقيم أقل من 067مج/ث وذللك في حالة استخدام البنزين (الوقود السائل) بكتل مختلفة. وقد بينت التجارب أبضا أن نقص معامل التهوية وزيادة معدلات التهوية يؤدي إلي تأثير ات غير مرغوبة حيث بزيد من لن

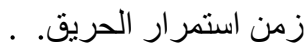

وثثت من التجارب العملية أن تأثير معامل التهوية ومعدلات التهوية على إخماد الحريق في حالة إنقاص معامل

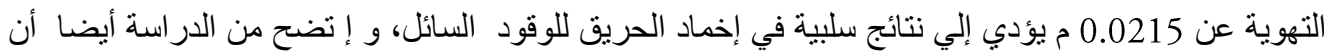
معدلات التهوية المنخفضة تكون مناسبة في حالة الوقود السائل. وبزيادة معامل التهوية وجد أن أعلي درجة حر ارة كانت لعو ادم الحريق كما أن طبقات عادم الحريق أظهرت أنها متر اصة بشكل مختلف بالمقارنة بالطبقات

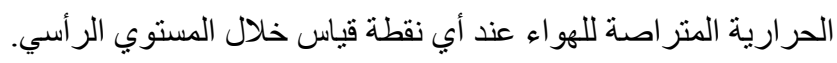

